\title{
Toward Philosophy of Science's Social Engagement
}

Francis Cartieri and Angela Potochnik

cartiefs@mail.uc.edu; angela.potochnik@uc.edu

Both at:

Department of Philosophy

University of Cincinnati

206 McMicken Hall ML 0374

Cincinnati, OH 45221-0374

\begin{abstract}
In recent years, philosophy of science has witnessed a significant increase in attention directed toward the field's social relevance. This is demonstrated by the formation of societies with related agendas, the organization of research symposia, and an uptick in work on topics of immediate public interest. The collection of papers that follows results from one such event: a three-day colloquium on the subject of socially engaged philosophy of science held at the University of Cincinnati in October 2012. In this introduction, we first survey the recent history of philosophy of science's social involvement (or lack thereof) and contrast this with the much greater social involvement of the sciences themselves (Section 1). Next, we argue that the field of philosophy of science bears a special responsibility to contribute to public welfare (Section 2). We then introduce as a term of art "socially engaged philosophy of science" and articulate what we take to be distinctive about social engagement, with reference to the articles in this collection as exemplars (Section 3). Finally, we survey the current state of social engagement in
\end{abstract}


philosophy of science and suggest some practical steps for individuals and institutions to support this trajectory (Section 4).

\section{Philosophy of Science and Society}

Soon after it was founded, the Philosophy of Science Association (PSA) was far more politically and socially oriented than it is today. One of the six categories suggested for submissions in the first issue of the Association's journal is dedicated to understanding the "function and significance of science within various contexts" (Phil. Sci. 1939, vol. 1, p. 4). The PSA bylaws established in 1948 are clear with regard to the social import of philosophy of science. That document states that the field should aim toward

The study and discussion of the subject of philosophy of science, broadly interpreted, and the encouragement of practical consequences which may flow therefrom of benefit to scientists and philosophers in particular and to men of good will in general (Phil. Sci. 1948, vol. 15, p. 176).

It is notable that this emphasizes the practical consequences of philosophy of science, including its consequences outside of philosophy. Philosophers are encouraged to take seriously the question of public welfare and to embrace the type of philosophical work that might have tangible benefits for scientists, citizens, and the relationship between the two.

As recently as the early 1950s, members of the PSA were encouraged to improve human welfare through the application of their views to social issues (Douglas 2009a). Earlier, Hans 
Reichenbach and Rudolph Carnap, the founders of Erkenntnis, stressed a similar aim. In his editorial for the first issue of this journal, Reichenbach invites the submission of work in scientific philosophy oriented toward resolving social problems (Erkenntnis 1930, vol. 1, p. 1-3). Among mathematicians, Reichenbach is known especially for his probabilistic decision theory, which grounds particular statements about probabilities in terms of the properties of random sequences. Yet it is notable that he employed and extended this highly technical theory in order to help understand difficult social structures arising from the demands of human welfare. According to Reichenbach,

If a decision is not made by one person but by a body of persons, such as a government, there are further random factors to be envisaged...the tiredness or sickness of leaders; the inertia of bureaucracy; the pleading of voices of people frightened by the horrors of war. All these factors are random factors and may extend in a positive or negative direction (1949, p.6).

Here, Reichenbach also embraces a broad interpretation of philosophy of science, for he considers how his technical work might be applied in a social context. His views extend beyond the fields of philosophy and mathematics to incorporate also the "pleading voices of people."

The social and political activity of the members of the Vienna Circle and associated philosophers, both in Europe in the interwar period and also in the US afterwards, is by now well appreciated (Friedman 1991, 1999; Reisch 2005a, 2005b; Friedman and Creath 2007; Uebel 2009, 2012). The Vienna Circle manifesto, coauthored by Carnap, Neurath, and Hahn in 1929, is explicit in its endorsement of a philosophy of science employed for the betterment of human 
welfare. The "scientific conception of the world" advocated there is intended to apply quite broadly:

We witness the spirit of the scientific world-conception penetrating in growing measure the forms of personal and public life, in education, upbringing, architecture, and the shaping of economic and social life according to rational principles (in Sarkar 1996, pp. 339-40).

This conception of philosophy of science has clear social dimensions. It is focally concerned with improving human welfare, for "the scientific world conception serves life, and life receives it" (ibid., p. 40). Carnap, Hahn, and Neurath held a view of philosophy of science according to which the discipline plays a "superstructural" role in society that has significant social and political components (Uebel 2005, pp. 756-7). In their view, a responsible, metaphysics-free philosophy of science goes hand-in-hand with particular economic, political, and ethical ideas. Philosophers are tasked with articulating and advocating these connections, as scientists themselves must focus their energies elsewhere.

According to Don Howard (2003), 1959 was the "watershed" year for philosophy of science's withdrawal from active social and political participation. This was the year that the mission of the Philosophy of Science Association changed dramatically, moving from the broad view of philosophy of science discussed above to a narrow view, one aimed at "the furthering of studies and free discussion from diverse standpoints in the field of philosophy of science" (Phil. Sci. 1959, vol. 26, p. 63). By 1961, the language in the PSA bylaws regarding philosophy of 
science's aim of practical benefits for all people had completely disappeared ${ }^{1}$ (Douglas 2012). Around this time, philosophers of science also ceased to be regular participants at the annual conference for the American Association for the Advancement of Science (AAAS) (Douglas 2009a). This withdrawal is telling. The AAAS is the world's largest scientific society, and it explicitly dedicates itself to serving society (as we discuss in greater detail below). This trend toward the social disengagement of philosophy of science has continued more or less uninterrupted until fairly recently.

The decreasing social engagement of philosophy of science is made more striking by an opposed tendency in the sciences toward increased social engagement. Scientists today have a plethora of organizations with the purpose of furthering science for the public good. Besides AAAS, there is the Nobel Foundation Rights Association, the Union of Concerned Scientists, and many others. Even at the stage of research design, major funding agencies increasingly require scientists to consider how their work benefits society. In 2014 the Higher Education Funding Council of England will begin using the Research Excellence Framework (REF), meant to ensure that funded research has clear benefits to the public (REF.ac.uk). The European Commission's seventh Framework Programme, set to grant $\$ 65$ billion to EU researchers from 2007-2013, judges all proposals in terms of their estimated societal impact (De Smedt 2010). The National Institutes of Health (NIH) selectively funds research that scores highly in terms of public significance (grants.nih.gov).

\footnotetext{
${ }^{1}$ Richard Rudner served as Editor-in-Chief of PSA from 1959-1974. In his resignation letter, Rudner suggests finding a future editor that can continue certain "non-doctrinaire" policies of focusing both on core issues in philosophy of science (explanation, prediction, verification, theory formation and change) and special areas of philosophy of science (philosophy of physics, philosophy of biology, philosophy of psychology, etc.). The absence of any socially or politically relevant topics on this list is especially notable, given Rudner's own active political involvement and his socially relevant philosophical work (Richard Rudner Archives).
} 
Perhaps the most illustrative example of science's trend toward social engagement is the National Science Foundation's (NSF) major changes in 1997 to how research proposals would be evaluated. Most notably, the "broader impacts" criterion was introduced as one of two merit criteria used for funding decisions. The NSF Grant Proposal Guide states that the criterion "encompasses the potential to benefit society and contribute to the achievement of specific, desired societal outcomes" (NSF GPG p.58). NSF director Arden Bement claims that "the criterion was established to get scientists out of their ivory towers and connect them to society" (Lok 2010, p.1). The broader impacts criterion encourages scientists to "contribute to the achievement of societally relevant outcomes" such as "increased public scientific literacy and public engagement with science and technology" and "improved well-being of individuals in society" (NSF GPG, p.25).

The AAAS's history of social involvement provides another effective contrast with philosophy of science's withdrawal from social concerns. The organization represents ten million members under the unifying mission to "advance science and serve society." In the 1960s the AAAS began to place an explicit emphasis on

Bringing underrepresented groups into science; applying science to human rights; supporting the growth of science in the developing world; exploring issues of science, ethics, and law; tracking federal spending for R\&D; and bringing scientists and engineers to work in Congress and executive agencies of government (AAAS.org archives 19411970). 
The AAAS was becoming more socially engaged just as philosophy of science was beginning to distance itself from social concerns. In 1985 AAAS initiated the '2061 project' to improve science literacy and extend the benefits of 'scientific thinking' to the general public, resulting in the book Science for All Americans, which is now a free online resource. The book includes the treatment of topics in history and philosophy of science in straightforward language, including scientific objectivity, the relation of theory to evidence and justification, the demarcation between science and non-science, explanation and prediction, and the social structure of science (AAAS 1990). The AAAS archives notes that these treatments are to be provided by "expert panels of scientists, mathematicians, and technologists" [AAAS.org archives 1971present]; the absence of philosophers of science from this list is telling. The resemblance between the social justification of "Science for All Americans" and the Vienna Circle's "Scientific Conception of the World" is striking:

Scientific habits of mind can help people in every walk of life to deal sensibly with problems that often involve evidence, quantitative considerations, logical arguments, and uncertainty; without the ability to think critically and independently, citizens are easy prey to dogmatists, flimflam artists, and purveyors of simple solutions to complex problems (AAAS 1990, p. xiv).

Neurath believed that philosophers of science could achieve these very same ends in much the same fashion--by extending the benefits of scientific rationality to citizens of democratic societies (Reisch 1994, p. 164). Even as this attitude has faded from philosophy of science, it has increasingly found expression in scientific communities and institutions. 
There is, though, some hope of a turnaround in philosophy of science's social disengagement, as a number of recent initiatives break from this pattern. Recent events and publications that have focused on philosophy of science and social issues include, for example, an American Philosophical Association (APA) mini-conference in 2008 on the topic of "Making Philosophy of Science More Socially Relevant"; a special issue in Synthese in 2010 on "Socially Relevant Philosophy of Science" ${ }^{2}$; and a conference on "advancing public philosophy" held in Washington D.C. in 2011, hosted by the newly-formed Public Philosophy Network (PPN). In addition, the Society for Philosophy of Science in Practice (SPSP) launched at PSA 2006 with the aim of "a philosophy of science that engages more closely with scientific practice, and with the practical uses of scientific knowledge" (SPSP meeting invitation). The newly formed Consortium for Socially Relevant Philosophy of/in Science and Engineering (SRPo/iSE) "organizes and promotes practitioners and institutions that use work at the intersection of philosophy and science/ technology to positively impact society" (srpoise.psu.edu). ${ }^{3}$ Finally, the Joint Caucus for Socially Engaged Philosophy and History of Science (JCSEPHS), newly formed under the aegis of the Philosophy of Science Association and the History of Science Society, was established at HSS/PSA 2012. The creation of JCSEPHS was catalyzed by the participants of University of Cincinnati's $49^{\text {th }}$ annual philosophy colloquium, an event that demonstrated the presence of a vibrant community of philosophers interested in a more "Socially Engaged Philosophy of Science," the theme of the conference and of this ensuing collection of papers.

\footnotetext{
${ }^{2}$ This special issue arose from an eponymous mini-conference at a 2010 APA meeting.

${ }^{3}$ SRPo/iSE is supported by philosophers at several academic institutions, including Kevin Elliott and Heather Douglas, both contributors to this issue.
} 


\section{Philosophy of Science's Social Obligations}

In this section we address the question of whether philosophers of science have a responsibility to engage with society in navigating scientific issues and conflicts. In her article in this issue, Heather Douglas develops a position regarding the moral obligations of scientists that provides an instructive parallel. Douglas draws on the notion of "role responsibility" to explore the moral demands placed upon scientists within democratic societies. A role responsibility is incurred when one accepts a role that accords understanding and abilities that, given one's social context, establishes a particular societal value. What responsibility is incurred depends on the value produced by the particular understanding and abilities associated with the role. In the case of science, Douglas claims that science's special value to society is its capability of producing "robust, reliable, empirical knowledge" (p.4). Practitioners of science have a special role responsibility, then, to adopt practices internal to science that protect and facilitate their ability to produce robust, reliable, empirical knowledge. Because the responsibility to ensure that science produces robust, reliable, empirical knowledge is often too onerous for any particular individual scientist to completely satisfy on their own, scientific communities incur a collective responsibility to provide and maintain institutional structures that fulfill scientists' role responsibility to society.

Douglas argues that there are three "bases" of the individual and collective role responsibilities of science, each affecting to what extent science produces its value to society: good scientific reasoning, a collaborative and cross-critical scientific community, and a functional relationship between science and society. Scientists, through diligent training in 
scientific values and methods, and through participation in collaborative scientific institutions, possess the understanding to satisfy the first two bases of their responsibility. But we question whether they are particularly well qualified to satisfy the third, which requires one to consider how science relates to the many competing values in democratic societies.

In the autumn of 1955, Richard Feynman gave a public address to the National Academy of Sciences in which he discussed the unique value of science to society. Feynman's work on the atomic bomb had, in part, made possible the killing of many thousands of people in Hiroshima and Nagasaki. With this in mind, he observed that "scientific knowledge is an enabling power to do either good or bad-but it does not carry instructions on how to use it" (p.1). The most prominent value of science to society, that it "enables us to do all kinds of things and to make all kinds of things" (p.1), is also its most prominent danger to society. Feynman illustrates this point further by alluding to a Buddhist parable, "To every man is given the key to the gates of heaven; the same key opens the gates of hell." This works as an analogy for science. Scientists, Feynman claims, are naïve when it comes to the questions of how science should operate and be disseminated in society, as well as how to pursue research with beneficial effects. Scientists are uniquely qualified to use empirical methods to learn about the world and to enable us to do and make all kinds of things. Yet, regarding the third base of science's responsibility that Douglas identifies, in Feynman's view a scientist is "just as dumb as the next guy...as naïve as anyone untrained in the matter" (Feynman, p.13). According to Douglas, the question of how scientific and social values should relate, interact, and integrate is "potent and central" (p.6). She is not alone in this view; Kitcher expresses the hope that "we achieve the needed integration in the time we have" $(2011$, p.248). The productive coordination of scientific and 
social values should not be shouldered by scientists alone, as they are not particularly qualified for this task.

In contrast, the training of philosophers of science is particularly useful in this connection. Philosophy of science offers a rich field of perspectives wide enough to capture the complexity of relations between science and society and critical enough to assess the underlying assumptions, interests, and histories of socio-scientific conflicts-and even to help resolve such conflicts. The skillset of philosophers of science, collectively, includes a special 'toolkit' of method and understanding. Methodologically, philosophers of science are trained in the use of critical analysis, skepticism, and dialogue as a means to generate understanding. This technique is extremely flexible, allowing philosophers to engage productively with a wide variety of topics. Philosophers of science are also equipped with knowledge of individual scientific subfields. Combined with training in dialogue and argument, this should prepare philosophers to act as mediators, educators, and advocates. These roles emphasize dialogue, critical treatment of multi-faceted arguments, and sensitivity to the values and interests of different perspectives. Perhaps most importantly, philosophy enables distance from the particular interests of stakeholders in debates. This impartiality allows for "a moderate view, one of advocating for reasons and rationalism rather than a particular political result" (Maienschein, this volume, p. 24).

All of this grounds, in our view, a role responsibility of philosophy of science to help mediate science's social position. Similar to what Douglas argues is the case in science, the role responsibility incurred by philosophers of science toward society is primarily a collective 
responsibility. One reason for this is that mediating the relationship between science and society is too onerous to be shouldered by individual philosophers of science. Additionally, it seems no individual philosopher of science has the obligation to pursue research with social relevance to the exclusion of her other interests. Instead, the responsibility of individual philosophers of science can be satisfied by supporting the creation and maintenance of institutional structures that help philosophy of science fulfill its collective responsibility. ${ }^{4}$

Many of the core topics in philosophy of science bear directly on a range of socioscientific conflicts, despite philosophers of science often distancing their work from these issues. For example, philosophical work on scientific practice can help reveal instances when arguments used to create public distrust of some scientific finding appeal to problematic scientific practices. The misrepresentation of responsible science and the application of bad scientific practices have been used to undermine scientific consensus on the causes of HIV/AIDS (Markoba 2002), the danger of genetically modified foods (Smith 2003), and the causes and severity of climate change (Dunlap et. al 2011). The related problem of demarcating science from non-science is controversial in philosophy of science and has received a great deal of attention. This was the central question in Tammy Kitzmiller, et al. v. Dover Area School District, et al. (400 F. Supp. 2 d 707, Docket no. 4cv2688)-the case that decided whether Intelligent Design could be taught in public schools. Philosophy of science might also contribute to public understanding of scientific uncertainty. Historians of science Naomi Oreskes and Erik Conway (2010) argue that the public tends to view science as something that provides certainty, "an

\footnotetext{
${ }^{4}$ Douglas distinguishes between role responsibilities and general responsibilities. Philosophers of science qua human beings may have a general responsibility to work to make the world a better place in one way or another, but we focus on role responsibilities, viz., whether philosophers of science have special responsibilities toward society in virtue of their chosen field.
} 
erroneous view of science" that allows powerful groups or individuals to undermine actions to address important social problems. Policy-makers similarly often fail to understand that uncertainty is a feature of all science, and this failure of understanding can have severe consequences. Sandra Mitchell argues that U.S. policy-makers depend on traditional costbenefit and 'predict and act' models, and that this dependence "can lead to ignoring the scientific knowledge we do have and prevent our policies from being informed by that science" (2009, p.4). Philosophers of science have endorsed decision-making models that accommodate scientific uncertainty (Popper et al, 2005, Mitchell 2009, Morgan and Henrion 1990).

Philosophers of science might also contribute to an improved public understanding of the diversity and variation of scientific methodology (Dupré 1990, Wylie 2000, Mitchell 2009). Many philosophers of science have cultivated an expertise on the methodological features of particular fields. For instance, Wendy Parker is expert in the peculiarities of climate science and is thus able to explain why methodological standards present in other areas of science, such as consistency and truth-preservation, are not appropriate in climate modeling (Parker 2006, 2010). In another case, Kevin Elliott applied his specialist knowledge of the hormesis phenomenon in environmental toxicology to discuss which particular societal values can be incorporated into assessments of public policy when human health is at stake, and how this can be done (Elliott 2011).

Perhaps most significantly, philosophers of science have developed an understanding of science as "a socially established and co-operative activity" (Gower 1997, p. 243). This has led an increasing number of philosophers to oppose the conception of science as 'value-free', a 
conception that is held by a majority of scientists, policy-makers, journalists, and the general public (Kitcher 2001). Douglas (2009b) identifies the need for scientists and policy-makers to make explicit the values that influence research design and execution, as well as the communication of results. But, as discussed above, scientists are not typically trained to identify the values at play in their research. Philosophers of science, in contrast, are well positioned for this by their "distinct role" - the nature of their professional activity and understanding (cf. Douglas, this issue).

Philosophers of science can do more than merely recognize values at play in science and society; they are also well-positioned to help improve how values are employed and to navigate socio-scientific conflicts. Feminist philosophy of science, in addition to identifying conceptions and practices that can subordinate gender and minority groups, "strives to reform these conceptions and practices" (Anderson 2012). One might argue that, because feminist philosophers of science have developed a special expertise in identifying practices that negatively impact subordinated groups, the field has incurred a collective role responsibility to contribute to the reform of those practices. Similarly, philosophy of science as a field has a collective responsibility to employ special expertise where it can contribute to human welfare. This responsibility arises because philosophers of science have cultivated a set of skills with special relevance to a variety of social issues. Failure to fulfill this collective responsibility constitutes a failure to improve public welfare in a way that would have been special to philosophy of science. We have surveyed a range of issues important to public welfare, aspects of which are particularly amenable to treatment by philosophers of science. These include unresolved socio-scientific conflicts that stand to do great harm to education (evolution vs. 
religion), research credibility (biased industry-funded research), public trust of science (ideology-based abuses of science), and even the long-term survival of our species (industrial and political attacks on climate science). Accordingly, in our view, philosophy of science has a collective responsibility to engage more directly and substantively with socio-scientific issues, with the aim of improving human welfare.

\section{Socially Engaged Philosophy of Science}

In this section we address the issue of what form a more socially involved philosophy of science should take. We articulate a program of research, education, and advocacy, undertaken by philosophers of science qua philosophers of science, with the aim of improving human welfare, which we dub "socially engaged philosophy of science" (SEPOS). Socially engaged philosophers of science identify issues arising from conflict or misunderstanding between scientific communities and citizens and apply the tools of philosophy of science to those issues. SEPOS is thus an extension of philosophy of science that leverages the distinctive expertise of the field as a public resource. This discussion is meant both to motivate a more socially engaged philosophy of science and to characterize the diverse set of projects by philosophers that are aimed at contributing to the public good.

For many reasons, contemporary philosophy of science lacks a dominant, socially conscious mission statement like the Vienna Circle's "Scientific Conception of the World." SEPOS, in turn, reflects the diversity of methods, goals, and values in different areas of science by treating socio-scientific issues locally. According to Kitcher, 
Three-quarters of a century's work has shown that different areas of Science are methodologically diverse, and that most of the interesting challenges and disputes within those areas resist the styles of formalization philosophers have wanted to impose" (2011, p.154).

Treating issues locally means attending to the distinctive scientific and social features of an issue. For example, the most successful climate modeling approaches incorporate several computational models that rely on assumptions that contradict one another (Parker 2006). These models thus cannot be strictly true of the world, and this might be used to undermine their credibility and to discourage their use in public-policy discussions. But such an attack on climate models can be diffused by revealing the distinctive methods and standards of justification at play and by addressing directly the issue of whether public officials-given their values and the values of the public they represent-should use the models to inform public policy. In contrast, it would be unhelpful to present public officials with a highly generalized account of scientific justification or to insist that public interest is not relevant to determining what methods are used. SEPOS has a local focus because methods and standards differ within science and because socio-scientific issues affect various communities of scientists and citizens differently. Viewing "science" and "the public" as homogenous is a mistaken oversimplification.

Despite its localized nature, SEPOS research, projects, and activities involve three general desiderata: public motive, specificity, and accessibility. These desiderata are not rigid requirements, but they help distinguish SEPOS from other projects in philosophy of science, including those that also have a social focus. We address each of these desiderata in turn. 
SEPOS has a public motive, for its principle motivation is to leverage the skillsets of philosophers of science to improve human welfare. In her contribution to this issue, Janet Kourany identifies the debate over the future of human enhancement as the most serious facing science and society in the $21^{\text {st }}$ century. Kourany worries that, without the participation of philosophers of science, the debate will stagnate, thereby negatively impacting human welfare. This is the expression of a public motive. Pursuant to our argument in Section 2, the improvement of human welfare should not be simply a secondary consequence of philosophical work with other aims, but is an important end goal of philosophy of science taken as a public resource. This public motive does not preclude SEPOS's contribution to technical discussions within philosophy of science. As demonstrated by Margaret Morrison's article in this issue, progress on traditional topics in philosophy of science, such as explanation and evidence, are a likely consequence of SEPOS, even with its focus on public welfare.

This public motive, along with SEPOS's local nature, in turn inspires the other two characteristic features of socially engaged philosophy of science. SEPOS most effectively pursues its public motive when it is specific to a particular socio-scientific issue and to the groups, individuals, or institutions with a stake in that issue. Specifying particular stakeholders and particular aspects of scientific issues of public concern ensures engagement with stakeholders' actual interests. For example, in his contribution to this issue, Kevin Elliott does not try to address the problem of scientific credibility in general. Rather, he focuses on particular stakeholders with particular values and interests-those who want to lessen the effects of biased research by creating criteria designed to recognize likely instances of compromised research credibility. Finally, SEPOS should be accessible to the stakeholders in an 
issue, viz., its style and venue must be appropriate for the particular stakeholders and the particular issue. Work is published in ways that reach relevant communities and is presented in terms that they will engage with. Because SEPOS is localized, the appropriate presentation style and venue will vary.

Taken together, these three desiderata capture what is distinctive about socially engaged philosophy of science. An example of how effective SEPOS satisfies these desiderata is Kristen Schrader-Freschette's work in the early 1990s to ameliorate conflicts between public, scientific, and political interests surrounding the storage of nuclear waste. This work was specific to a particular socio-scientific problem at the height of its societal relevance, motivated by concern for public welfare, and delivered in a way that was accessible to different stakeholders in the waste-storage dispute (Schrader-Freschette, 1993). The papers comprising this issue also exemplify the characteristics of SEPOS; here we address each in turn.

In his contribution, Kevin Elliott addresses the social problem of industry and government agencies engaging in misleading research designed to confuse the public on a range of important issues. The work's principal concern is thus public welfare. Elliott targets the issue of research credibility in part because it is a topic in philosophy of science's wheelhouse. He points out that credibility is really just a question about how evidence bears on some claim -a relation that has been exhaustively explored by philosophers of science. The issue is an immediate social problem, and one of increasing importance. Industry-funded research increasingly targets unfavorable independent results from other researchers, resulting in public suspicion of credible science (cf. Conway and Oreskes 2004). Elliott suggests a practical way 
forward; he recommends a reasonable criterion for determining the credibility of studies. Importantly, his recommendation is specific and accessible to those involved in the issue.

In her contribution, Margaret Morrison argues that we need to distinguish between subjective features in computational modeling, and what we call "value judgments." To fail to distinguish the two is to fail to isolate the potentially harmful influence of pernicious value judgments from other subjective influences that are known and accounted for. Morrison identifies NASA's Columbia disaster as one in which subjective features and value judgments should be distinguished. Engineers evaluated the risk of foam damage to the Space Shuttle with a computational risk assessment program designed to account for small debris (a subjective feature), but NASA chose to apply the program outside its domain of application for reasons of cost and ease of use (a value judgment). It was the value judgment that primarily contributed to the destruction of Columbia, rather than the subjective features of the risk-assessment program. Morrison's project is thus motivated to contribute to human welfare by providing a means for distinguishing more harmful value judgments from subjective influences in science. More, the project is specified to a particular context, computational risk-assessment, in a way that is sensitive to the local features of that current socio-scientific problem.

Heather Douglas employs philosophical tools to identify the value commitments of scientists and to situate them in a moral structure governing participation in science. She recognizes that prior attempts to articulate the responsibilities of scientists have been either too restrictive or too simplistic, and that articulating an appropriate set of moral responsibilities for scientists is in the public and scientific interest. Notably, Douglas blames past failures to 
articulate the moral terrain of science in part on the absence of contributions from philosophers of science. Douglas puts her account to work on a case study of the controversial publication of potentially dangerous $\mathrm{H} 1 \mathrm{~N} 1$ research findings, in which public and scientific values conflict.

In her contribution, Janet Kourany asks whether philosophers of science might help to make the debate surrounding human enhancement (pharmaceutical, biological, nanotechnological, etc.) a more productive one. The human enhancement issue is of immediate social import, not least because the benefits of enhancement science are likely to disproportionally favor the wealthy. Kourany suggests specific areas of the debate to which philosophers of science can contribute, such as in specifying a framework of values among the debate's stakeholders. By making explicit the local values of scientists, policy-makers, and public constituencies, philosophers of science can allow the debate to proceed more rationally and productively. Kourany's article illustrates one way in which SEPOS can help address Feynman's worry that scientists are naïve regarding how science can best serve society's interests.

Crucial to our articulation of SEPOS, and in particular the desideratum of a public motive, is the incorporation of activities beyond philosophical research, including advocacy and education. In her article, Jane Maienschein discusses the role of the philosopher of science as a direct participant in the relationship between science and society. She notes that, despite an increasing tendency of philosophers of science to stress the social context of science, many still resist direct social engagement. While developing a philosophical understanding of science in 
social context must be an element of SEPOS, the current state of that understanding is often sufficiently developed to support attempts to participate "on the ground level" of socioscientific issues. Maienschein's prior work as Science Advisor to Congressman Matt Salmon illustrates a form of direct social engagement. Maienschein stresses that social engagement requires philosophers to be ready to react to socially significant developments as they occur. This results in part from attending to debates that are of current importance to the public, even if they are not philosophically nuanced enough to be of intrinsic interest in philosophy of science.

\section{Moving Forward}

In the introduction to a 2010 special issue of Synthese, "Socially Relevant Philosophy of Science," Carla Fehr and Kathryn Plaisance maintain that socially relevant philosophy of science should be encouraged, both for its contributions to traditional philosophical problems and its potential benefits for science and society. They argue for an expansion of socially relevant philosophy of science, and they situate such projects within general philosophy of science. We endorse this effort to make socially relevant work more central to philosophy of science. Indeed, one of the most significant impediments to SEPOS is the view that issues of social relevance are somehow outside the core issues in philosophy of science. That said, we also see a pressing need for more philosophers of science to move beyond producing socially relevant work, to actually effecting social change with their work. Socially engaged philosophy of science thus leverages philosophy of science as a public resource; under SEPOS this effect is intentional 
and primary rather than incidental and secondary (see Section 3). Here we survey the current state of SEPOS, and we suggest some additional steps that philosophers of science can take to support SEPOS, thus helping to discharge the collective social responsibility of the field.

Fortunately, there are many signs of a trend toward greater social engagement. As mentioned above, participants in the University of Cincinnati Colloquium on Socially Engaged Philosophy of Science spearheaded the creation of the Joint Caucus of Socially Engaged Philosophers and Historians of Science (JCSEPHS) of the Philosophy of Science Association and the History of Science Society. JCSEPHS has released a Manifesto, reminiscent of the Vienna Circle's Manifesto, that is evocative of SEPOS as we have developed the concept here. Helen Longino and Sandra Mitchell orchestrated an inaugural meeting of the caucus at the 2012 HSS/PSA Joint Session. The meeting involved an enthusiastic, standing-room only crowd with diverse views in philosophy and history of science. This demonstrated the tremendous amount of untapped interest in SEPOS. JCSEPHS is currently preparing a website with resources to support SEPOS. Plans include a repository of relevant teaching modules, a section for public discussions of socially engaged history and philosophy of science in a global context, and a database of the public expertise of JCSEPHS members. The need for such a database was underlined at the inaugural JSCEPHS meeting, where a representative of AAAS expressed the regret that the organization did not have a way to reach out to philosophers and historians with relevant expertise.

The establishment of JCSEPHS as a resource within philosophy and history of science is encouraging. Other opportunities are created through involvement with scientific organizations 
purposed toward serving society, such as AAAS. Philosophers of science have recently begun to reestablish a presence at the annual AAAS conference. Sandra Mitchell and Naomi Oreskes currently serve on the program committee for AAAS, and Jane Maienschein, a contributor to this issue, served as president of Section L (History and Philosophy of Science) in $2012 .^{5}$ AAAS supports fellowships to provide non-scientists with the training and experience to take part in advocacy at the interface between science and society. Similar advocacy support exists at other organizations as well, including the Commission on Professionals in Science and Technology, the British Association for the Advancement of Science, the US National Academy of Sciences, the National Institutes of Health, and the National Science Foundation. Such opportunities to gain familiarity with public-policy design, evaluation, and implementation are tremendously helpful for SEPOS.

Another opportunity to further SEPOS is working to change the incentive structure in philosophy departments and the field as a whole. Many philosophy departments in the US provide little or no professional incentives for philosophers of science to engage with the general public. Indeed, as Maienschein notes in this issue, graduate students and junior faculty in philosophy of science face a competitive atmosphere that tends to discourage social engagement in favor of more traditional professional aims. Faculty and administrators might work to introduce incentives for the social engagement of young philosophers, such as awards, explicit incorporation of this aim into research initiatives, or an emphasis on social engagement in hiring and tenure criteria. For instance, on her Notre-Dame website, Kristin Shrader-

\footnotetext{
${ }^{5}$ The current chair of AAAS section $\mathrm{L}$ is philosopher of science Davis Baird. For more information on the membership and activities of AAAS section L, visit http://www.aaas.org/aboutaaas/organization/sections/history/
} 
Frechette explains how she integrates public-policy work into students' research by asking them to apply their ethical and philosophical training to improve actual pieces of legislation, such as the Los Alamos Laboratory's 1999 Environmental Impact Statement. Young philosophers might also be encouraged to participate in training programs in science policy and education. For example, Arizona State University's Consortium for Science, Policy \& Outcomes (CSPO) supports philosophers' participation in a two-week science-policy training program in Washington, D.C.

Finally, philosophers are increasingly publishing and publicizing their work beyond traditional philosophy and philosophy of science venues. One example of this is the openaccess, online journal Philosophy and Theory in Biology started in 2009, which has the explicit mission of facilitating interaction among philosophers of science and theoretically minded biologists. Another example is the AAAS blog Scientia, created by Manfred Laubichler in 2010 with the aim of "[e]xploring the multiple ways history can inform current scientific debates and contributing to more integrated perspectives on science in society." Its articles have frequently been among the most viewed and commented upon across more than 300 AAAS blogs. Above, we emphasized the goal of accessibility, which ensures that work can be discovered and engaged with by non-philosophers. An increased interest in social engagement should be matched by institutional recognition of work published in non-philosophy journals or presented outside traditional philosophy meetings.

We are optimistic that SEPOS is emerging from shifting attitudes in philosophy of science. After a long period of social and political disengagement, the field and its participants 
are taking steps to assert the availability of philosophy of science as a public resource. The examples we give here and the contributions to this journal issue are, of course, merely a sample of that progress.

\section{Resources}

\begin{tabular}{|c|c|}
\hline Philosophy & \\
\hline JCSEPHS listserv & jcsephs@googlegroups.com \\
\hline SPSP & http://www.philosophy-science-practice.org/ \\
\hline SRPo/iSE & http://srpoise.psu.edu/ \\
\hline $\begin{array}{l}\text { APA committee on public } \\
\text { philosophy }\end{array}$ & http://www.publicphilosophy.org/index.html \\
\hline Public Philosophy Network & http://publicphilosophynetwork.ning.com/ \\
\hline \multicolumn{2}{|l|}{ Science and Policy } \\
\hline $\begin{array}{l}\text { AAAS Science and Policy } \\
\text { fellowships }\end{array}$ & http://fellowships.aaas.org/ \\
\hline $\begin{array}{l}\text { AAAS Government Relations } \\
\text { internships }\end{array}$ & http://www.aaas.org/gr/about/intern.shtml \\
\hline Union of Concerned Scientists & http://www.ucsusa.org/ \\
\hline $\begin{array}{l}\text { Center for Science and } \\
\text { Democracy }\end{array}$ & http://www.ucsusa.org/center-for-science-and-democracy/ \\
\hline The National Research Council & http://www.nationalacademies.org/nrc/ \\
\hline US scientific integrity policies & $\begin{array}{l}\text { http://www.whitehouse.gov/administration/eop/ostp/library } \\
\text { /scientificintegrity }\end{array}$ \\
\hline \multicolumn{2}{|l|}{$\begin{array}{l}\text { Education and Public } \\
\text { Engagement }\end{array}$} \\
\hline $\begin{array}{l}\text { International History, } \\
\text { Philosophy, and Science } \\
\text { Teaching Group }\end{array}$ & http://ihpst.net/ \\
\hline $\begin{array}{l}\text { Center for Public Engagement } \\
\text { with Science and Technology }\end{array}$ & http://www.aaas.org/programs/centers/pe/index.shtml \\
\hline $\begin{array}{l}\text { National Coordinating Center } \\
\text { for Public Engagement }\end{array}$ & http://www.publicengagement.ac.uk/ \\
\hline Academic Institutions & \\
\hline
\end{tabular}




\begin{tabular}{|l|l|}
\hline $\begin{array}{l}\text { ASU Consortium for Science, } \\
\text { Policy, and Outcomes }\end{array}$ & http://www.cspo.org/ \\
\hline $\begin{array}{l}\text { Boulder Center for Science and } \\
\text { Technology Policy Research }\end{array}$ & http://sciencepolicy.colorado.edu/ \\
\hline $\begin{array}{l}\text { OSU Battelle Center for Science } \\
\text { \& Technology Policy }\end{array}$ & http://www.battellecenter.org/ \\
\hline $\begin{array}{l}\text { ND Reilly Center for Science, } \\
\text { Technology, and Values }\end{array}$ & http://reilly.nd.edu/ \\
\hline
\end{tabular}




\section{References}

-American Association for the Advancement of Science. (1990). Science for all Americans (Project 2061). New York: Oxford University Press.

-American Association for the Advancement of Science. (2013). 150 Years of Advancing Science: A History of AAAS. http://archives.aaas.org/exhibit/historyexhibit.php

-Anderson, E. (2012). "Feminist Epistemology and Philosophy of Science", The Stanford Encyclopedia of Philosophy, Edward N. Zalta (ed.).

-De Smedt, P. (2010). The use of impact assessment tools to support sustainable policy objectives in Europe. Ecology and Society, 15(4), 30.

-Dietrich, M., Skipper, R.A. 2007. Manipulation underdetermination in scientific controversy: The case of the molecular clock. Perspectives on Science 15:3 295-326.

-Douglas, H. (2009a). Philosophy of Science, Political Engagement, and the Cold War: An Introduction. Science \& Education, 18(2), 157-160.

-Douglas, H. E. (2009b). Science, policy, and the value-free ideal. Pittsburgh: University of Pittsburgh Press.

-Douglas, H. (2012). A History of the PSA Before 1970. www.philsci.org/about/history.html -Dunlap, R. E., McCright, A. M. (2011). "Climate Change Denial: Sources, actors, and strategies". In Constance Lever-Tracy. Routledge Handbook of Climate Change and Society. Taylor \& Francis.

-Dupré, J. (1990). Scientific pluralism and the plurality of the sciences: Comments on David Hull's Science as a Process. Philosophical Studies, 60(1), 61-76.

-Elliott, K. (2011). Is a Little Pollution Good for You? Incorporating Societal Values in Environmental Research, Oxford University Press.

-Feynman, R. P. (1955). The value of science. Engineering and Science, 19(3), 13-15.

-Friedman, M. (1991). The re-evaluation of logical positivism. The Journal of Philosophy, 88(10), 505-519.

-Friedman, M. (1999). Reconsidering logical positivism. Cambridge University Press. -Friedman, M., \& Creath, R. (Eds.). (2007). The Cambridge Companion to Carnap. Cambridge University Press. 
-Gower, B. 1997. Scientific Method: An Historical and Philosophical Introduction. London: Routledge.

-Howard, D. (2003). Two left turns make a right: On the curious political career of North American philosophy of science at midcentury. Logical Empiricism in North America, 25-93.

---(2009). Better red than dead--Putting an end to the social irrelevance of postwar philosophy of science. Science and Education, 18, 199-220.

-Kitcher, P. (2001). Science, Truth, and Democracy. New York: Oxford University Press. -Kitcher, P. (2011). Science in a democratic society. New York: Prometheus Books. -Lok, Corie. (2010) "Science funding: Science for the masses." Nature, 465, 416-418 -Markoba MW (May 2002). "Politics, the media and science in HIV/AIDS: the peril of pseudoscience". Vaccine (journal) 20 (15): 1899-904.

-Mitchell, S. D. (2009). Unsimple truths: Science, complexity, and policy. Chicago: University of Chicago Press.

-Morgan, M. G., Henrion, M. 1990. Uncertainty: A guide to dealing with uncertainty in quantitative risk and policy analysis. Cambridge: Cambridge University Press.

-The National Science Foundation. (2013). Proposal and Award Policies and Procedures Guide Part I: Grant Proposal Guide. http://www.nsf.gov/pubs/policydocs/pappguide -Oreskes, N, Conway, E.M. 2010. Merchants of Doubt: How a Handful of Scientists Obscured the Truth on Issues from Tobacco Smoke to Global Warming. New York: Bloomsbury Press. -Parker, W. S. (2006). Understanding pluralism in climate modeling. Foundations of Science, 11(4), 349-368.

-Parker, W. S. (2010). Predicting weather and climate: Uncertainty, ensembles and probability. Studies in History and Philosophy of Science Part B: Studies in History and Philosophy of Modern Physics, 41(3), 263-272.

-Popper, S. W. Lempert, R. J. Bankes, S. C. 2005. Shaping the future. Scientific American 292(4): 66-71.

-Reichenbach, H. (1949). Rational Reconstruction of the Decision for War. RAND-D 539. -Reisch, G. A. (1994). Planning science: Otto Neurath and the International Encyclopedia of Unified Science. British journal for the history of science, 27(93), 153-176. 
-Reisch, G. A. (2005a). How the cold war transformed philosophy of science: To the icy slopes of logic. New York: Cambridge University Press.

-Reisch, G. A. (2005b). Three kinds of political engagement for philosophy of science. Science and Education, 18, 191-197.

-Sarkar, Sahotra. (1996). The Emergence of Logical Empiricism: From 1900 to the Vienna Circle. New York: Garland Publishing.

-Schiebinger, L. (1999) Has Feminism Changed Science? Boston, MA: Harvard University Press.

Smith, J. M. (2003). Seeds of deception. lowa: Yes! Books.

-Shrader-Frechette, K. (1993). Burying uncertainty: Risk and the case against geological disposal of nuclear waste. Berkeley: University of California Press.

-Uebel, T. (2005). "Political Philosophy of Science in Logical Empiricism: The Left Vienna Circle", Studies in History and Philosophy of Science, 36: 754-773

-Uebel, T. (2009). Knowing who your friends are: Aspects of the politics of logical empiricism. Science \& Education, 18(2), 161-168.

-Uebel, T. (2012). Carnap, Philosophy and "Politics in its Broadest Sense". Rudolf Carnap and the Legacy of Logical Empiricism, 133-148.

-Wylie, A. (2000). Questions of evidence, legitimacy, and the (dis) unity of science. American antiquity, 227-237. 